\title{
THE EFFECT OF USING THE YANBU'A METHOD ON THE ABILITY TO READ THE AL-QUR'AN SANTRI IN PONDOK PESANTREN AL-BADAR KECAMATAN PAMIJAHAN BOGOR
}

\section{PENGARUH PENGGUNAAN METODE YANBU'A TERHADAP KEMAMPUAN MEMBACA AL-QUR'AN SANTRI DI PONDOK PESANTREN AL-BADAR KECAMATAN PAMIJAHAN BOGOR}

\author{
Agus Sarifudin ${ }^{1}$, Nana Ernawati ${ }^{2}$ \\ STAI Al-Hidayah Bogor \\ email:agus_sarifudin65@yahoo.com
}

Received: 30/07/2020, Accepted: 25/08/2020, Published: 29/08/2020

\begin{abstract}
The Yanbu'a method is a tariqah reading and writing and memorizing Al-Qur'an, which was first published in 2004 by the Arwaniyyah Foundation for the Yanbu'ul Qur'an Kuddus Islamic Boarding School. This study aims to describe the use of the Yanbu'a method for the students' reading ability of the Al-Qur'an at Pondok Pesantren Al-Badar Pamijaan Bogor. This research method is quantitative research. The subjects of this study were students of Al-Badar Islamic Boarding School. The data sources of this research were distributing questionnaires to 20 students, interviews with the leaders of the Al-Badar Islamic Boarding School and the Ustadz / ah, the students 'recitation activities, and the results of the students' development achievement cards. The instruments in this study were (1) the students' achievement card to read the Al-Qur'an to gain progress in reading the Al-Qur'an during the use of the Yanbu'a method, (2) a questionnaire test to obtain data on the results of using the Yanbu'a method on their ability. Students read the Qur'an. The results of this study indicate the conclusions (1) The use of the Yanbu'a method at Al-Badar Islamic Boarding School is in a suitable category (2) The ability to read the Al-Qur'an of students at Al-Badar Islamic Boarding School is in the first category (3) There is a positive correlation. The strong or high between the use of the Yanbu'a method on the ability to read the Al-Qur'an of the students at Al-Badar Islamic Boarding School, which is 0.89.

Keywords: quantitative, yanbu'a method, tariqah, Al-Qur'an
\end{abstract}

\begin{abstract}
ABSTRAK
Metode Yanbu'a merupakan salah satu thariqah baca tulis dan menghafal Al-Qur'an yang pertama kali diterbitkan pada tahun 2004 oleh Yayasan Arwaniyyah Pondok Pesantren Yanbu'ul Qur'an Kuddus. Penelitian ini bertujuan untuk mendeskripsikan penggunaan metode Yanbu'a terhadap kemampuan membaca Al-Qur'an santri di Pondok Pesantren Al-Badar Pamijaan Bogor. Metode penelitian ini merupakan penelitian kuantitatif. Subjek penelitian ini adalah santriawan/i Pondok Pesantren Al-Badar. Sumber data penelitian ini adalah menyebar angket kepada santriawan/i sebanyak 20 santri, wawancara kepada Pimpinan Pondok Pesantren Al-Badar beserta Ustadz/ah, kegiatan mengaji santri, dan hasil kartu prestasi perkembangan santri. Instrumen pada penelitian ini adalah (1) Kartu prestasi membaca AlQur'an santri untuk memperoleh perkembangan membaca Al-Qur'an santri selama menggunakan metode Yanbu'a, (2) Tes angket untuk memperoleh data hasil penggunaan metode Yanbu'a terhadap kemampuan membaca Al-Qur'an santri. Hasil penelitian ini menunjukkan kesimpulan (1) Penggunaan metode Yanbu'a di Pondok Pesantren Al-Badar termasuk dalam kategori baik (2) Kemampuan membaca Al-Qur'an santri di Pondok Peseantren Al-Badar temasuk dalam kategori baik (3) Terdapat korelasi positif yang kuat atau tinggi antara penggunaan metode Yanbu'a terhadap kemampuan membaca Al-Qur'an santri di Pondok Pesantren Al-Badar, yaitu sebesar 0,89.

Kata kunci: kuantitatif, metode yanbu'a, thariqah, Al-Qur'an
\end{abstract}




\section{A. PENDAHULUAN}

Berdasarkan catatan statistic The New Pew Forum on Religion \& Public Life pada tahun 2010, Negara Indonesia menempati urutan pertama dari sepuluh negara dengan populasi muslim terbesar di dunia. Persentase Muslim Indonesia mencapai hingga 12,7 persen dari populasi dunia. Dari 205 juta penduduk Indonesia, dilaporkan sedikitnya 88,1 persen beragama Islam. (http://www.republika.co.id/ berita/dunia-islam/islam-

nusantara/15/05/27/ noywh5-inilah-10negara-dengan- populasi-muslim-terbesardi-dunia Diunduh pada 07 Januari 2017). Hal ini menjadi sebuah fenomena menarik bagi pertumbuhan jumlah umat muslim dunia khususnya Indonesia yang memiliki keberagaman agama dengan jumlah etnik yang majemuk.

Namun, fakta di lapangan menunjukkan masih banyak umat Islam Indonesia dari berbagai kalangan belum mampu menjalankan dan mengamalkan agamanya. Hal ini tidak hanya dapat kita temukan di wilayah perkotaan saja yang dalam persepsi mayoritas penduduknya telah terisolir dengan berbagai dinamika hidup yang kompleks. Akan tetapi pengaruh budaya asing yang terbawa oleh kemajuan teknologi telah masuk ke wilayah pedesaan, serta berbagai faktor lain yang menyebabkan rendahnya tingkat pengetahuan dan pengamalan dalam beragama.

Usaha sadar dan yang paling mendasar adalah dengan mempelajari Al-Qur'an sebagai sumber utama ajaran pokok agama yang disyari'atkan Allah kepada manusia sebagai pedoman hidup untuk mencapai kebahagiaan dunia dan akhirat, serta membacanya

merupakan ibadah yang ditinggikan pahalanya oleh Allah S.W.T.

H. Ramli Abdul Wahid, 2002; 232 mngungkapkan dan menyebutkan bahwa dalam kitab shahih Imam Bukhari meriwayatkan sebuah hadits dari Hajjaj bin Minhal dari Syu'bah dari Al-Aqamah bin Martsad dari Sa'ad bin Ubaidillah dari Abu Abdirrahman As-Sulami:

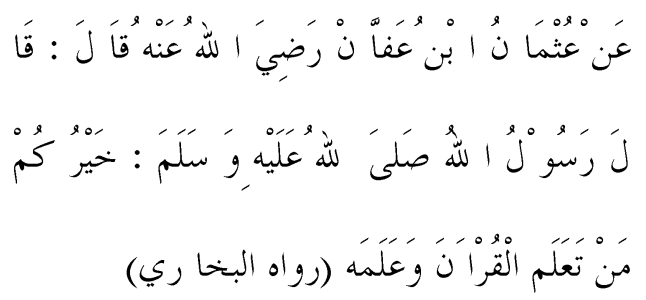

Dari Usman ibn Affan r.a. berkata, Rasulullah S.A.W. bersabda: Sebaikbaik kalian ialah orang yang mempelajari Al-Qur'an dan yang mengajarkannya. (H.R. Al-Bukhari).

Berdasarkan tafsir hadits di atas menunjukkan bahwa mempelajari AlQur'an mencakup di dalamnya belajar 
untuk membaca lafadz-lafadz yang terdapat dalam Al-Qur'an dengan ilmu dan kaidah yang diajarkan seorang guru agar tidak keliru dalam memaknai lafadz yang terkandung dalam setiap ayat Al-Qur'an yang dibaca.

Pada tahun 1950 sekitar 17,5\% remaja Islam Indonesia tidak bisa membaca AlQur'an sedangkan pada tahun 1980 telah mencapai angka 56\%. Tahun 1990 survey diadakan khusus di DKI Jakarta sekitar 75\% siswa SMA tidak dapat membaca AlQur'an. Survey yang dilakukan oleh Institut Ilmu Al-Qur'an (IIQ) Jakarta pada tahun 2011 menyebutkan bahwa 65\% umat Islam Indonesia buta aksara Al-Qur'an, 35\% hanya dapat membaca Al-Qur'an saja sedangkan yang mampu membaca dengan benar hanya $20 \%$. Sedangkan survey yang dilakukan oleh lembaga Survey Sosial Ekonomi Nasional (SUSENAS) 2013 BPS mengemukakan bahwa 53,8\% ummat Islam Indonesia tidak dapat membaca Al-Qur'an (http://www.republika.co.id/ berita/duniaislam/islam-nusantara /14/11/12/news-tingkatbuta-huruf-al-qur'an-masih-tinggi-ini-

komentar-kemenag. Diunduh pada 29 Maret 2016).

Berdasarkan fenomena yang terdata di atas menunjukkan bahwa jumlah umat Islam Indonesia yang mampu membaca AlQur'an masih sangat memprihatinkan. Sehingga memunculkan ide dari berbagai pihak dan lembaga pendidikan keagamaan untuk menciptakan metode cepat dan tepat untuk dapat meningkatkan kemampuan membaca Al-Qur'an yang sesuai dengan kaidah-kaidah keilmuan yang berlaku.

Kaitannya dengan hal ini, pesantren sebagai lembaga keagamaan yang menyelenggarakan pendidikan Al-Qur'an ikut berperan aktif untuk menekan angka buta aksara Al-Qur'an di Indonesia. Tidak terkecuali dengan Pondok Pesantren Salaf Al-Badar yang terletak di Desa Pamijahan Kecamatan Pamijahan Kabupaten Bogor.

Pondok pesantren yang berdiri sejak tahun 1975 M / 1396 H ini, sudah banyak menerapkan metode membaca Al-Qur'an kepada para santri dari mulai metode AlBaghdadi, metode Iqro', metode Qiro'ati, dan yang paling terakhir menggunakan metode Yanbu'a yang memang belum banyak digunakan di beberapa lembaga sekitar. Dalam hal ini, peneliti merasa tertarik untuk lebih lanjut meneliti tingkat kemampuan membaca Al-Qur'an santri dengan penggunaan metode Yanbu'a di Pondok Pesantren Al-badar.

Berangkat dari pernyataan dan kenyataan tersebut maka penelitian berjudul "PENGARUH PENGGUNAAN METODE YANBU'A TERHADAP KEMAMPUAN MEMBACA ALQUR'AN SANTRI DI PONDOK 
PESANTREN

AL-BADAR

KECAMATAN PAMIJAHAN BOGOR".

\section{B. TUJUAN PENELITIAN}

Berdasarkan pokok pembahasan di atas, maka dapat diketahui tujuan dari penelitian ini yaitu:

1. Untuk mengetahui penggunaan metode Yanbu'a di Pondok Pesantren AlBadar Desa Pamijahan Bogor.

2. Untuk mengetahui kemampuan membaca Al-Qur'an santri di Pondok Pesantren Al-Badar Desa Pamijahan Bogor.

3. Untuk mengetahui pengaruh penggunaan metode Yanbu'a terhadap kemampuan membaca Al-Qur'an santri di Pondok Pesantren Al-Badar Desa Pamijahan Bogor.

\section{KAJIAN TEORITIS}

1. Penggunaan Metode Yanbu'a

\section{a. Definisi Penggunaan Metode Yanbu'a}

Menurut Kamus Besar Bahasa Indonesia (KBBI) penggunaan merupakan akar kata dari kata guna yang dapat diartikan sebagai perbuatan menggunakan sesuatu (W.J.S. Poerwadarminta, 2011: 390). Metode berasal dari bahasa Yunani, yaitu "methodos". Kata ini terdiri dari dua suku kata, yaitu metha yang berarti melalui atau melewati, dan hodos yang berarti jalan atau cara untuk mencapai tujuan. Dalam bahasa Arab disebut dengan thariqah yang berarti langkah strategis yang dipersiapkan untuk melakukan sesuatu (H. Ramayulis, 2015: 264). Sedangkan metode Yanbu'a merupakan metode membaca, menulis dan menghafal Al-Qur'an secara bertahap yang diterbitkan oleh tim penyusun $\mathrm{KH}$. Ulil Albab Arwani dari Pondok Pesantren Yanbu'ul Qur'an Kudus. Bila dihubungkan dengan istilah penggunaan metode Yanbu'a, maka dapat didefinisikan sebagai kegiatan menggunakan panduan sistematis yang dapat digunakan untuk meningkatkan kemampuan membaca, menulis dan menghafal Al-Qur'an dengan baik dan benar secara bertahap yang diprakarsai oleh KH. M. Ulil Albab Arwani dan telah berhasil diterbitkan pada tahun 2004.

Berdasarkan pandangan filosofis pendidikan, metode merupakan alat yang dipergunakan untuk mencapai tujuan pendidikan. Dalam fungsinya sebagai alat, Yanbu'a dapat 
dikategorikan sebagai metode polipragmatis yaitu metode yang memiliki kegunaan serba ganda (multipurpuse) dimana dalam kondisi tertentu dapat digunakan untuk membangun atau memperbaiki hasil pembelajaran.

Ramayulis menjelaskan bahwa metode pendidikan Islam sangat menghargai kebebasan individu selama kebebasan itu sejalan dengan fitrahnya. Maka dalam hal ini, seorang pendidik dituntut untuk yang mengarahkan, mengembangkan potensi peserta didik dengan menggunakan metode-metode yang tepat serta efektif. (H. Ramayulis, 2015: 264). Metode Yanbu'a dalam penerapannya mengupayakan anak aktif dan mandiri untuk mengukur kemampuan membaca Al-Qur'an masing-masing tanpa dituntun. Peran guru tidak hanya mengarahkan anak, akan tetapi membina dan melatih dengan seksama.

\section{b. Dasar-dasar Penggunaan Metode} Yanbu'a

1) Dasar Al-Qur'an dan Hadits

2) Dasar Yuridis
Kebijakan pemerintah dalam penyelenggaraan pendidikan AlQur'an di pondok pesantren secara legalitas-normatif diatur dalam Peraturan Menteri Agama Republik Indonesia Nomor 13 Tahun 2014 tentang Pendidikan Keagamaan Islam sebagai pelaksanaan dari Peraturan Pemerintah Nomor 55 Tahun 2007 tentang pendidikan Agama dan Pendidikan Keagamaan dan Undang-Undang Nomor 20 Tahun 2003 sebagai dasar pijakan tujuan pendidikan nasional.

Berikut pemaparan mengenai dasar yuridis penggunaan metode Yanbu'a di pondok pesantren sebagai lembaga yang menyelenggaraan pendidikan keagamaan antara lain:

Lampiran Peraturan Menteri Agama Republik Indonesia Nomor 13 Tahun 2014 tentang Pendidikan Keagamaan Islam BAB I Ketentuan Umum bahwa:

Pendidikan keagamaan Islam adalah pendidikan yang mempersiapkan peserta didik untuk dapat menjalankan peranan yang menuntut penguasaan pengetahuan tentang ajaran agama Islam dan/atau menjadi ahli ilmu agama 
Islam dan mengamalkan ajaran agama Islam.

(Pasal 1 angka 1)

Pondok pesantren yang selanjutnya disebut pesantren adalah lembaga pendidikan keagamaan Islam yang diselenggarakan oleh masyarakat yang menyelenggarakan satuan pendidikan pesantren dan/atau secara terpadu menyelenggarakan jenis pendidikan lainnya.

(Pasal 1 angka 2)

Pesantren sebagai satuan pendidikan pasal 14 angka 1

Muatan kurikulum pesantren sebagai satuan pendidikan meliputi Al-Qur'an, Tafsir, Ilmu Tafsir, Hadits, Ulum Al-Hadits, Tauhid, Fiqh, Ushul Fiqh, Akhlak, Tasawuf, Tarikh, Bahasa Arab, Nahwu Sharaf, Balaghah, Ilmu Kalam, Ilmu 'Arudl, Ilmu Manthiq, Ilmu Falaq, dan disiplin ilmu lainnya.

(Pasal 14 angka 1)

Pendidikan Al-Qur'an adalah lembaga penddikan keagamaan Islam yang bertujuan untuk memberikan pengajaran pengajaran bacaan, tulisan, hafalan, dan pemahaman AlQur'an.

(Pasal 1 angka 11)
Pesantren menyelenggarakan pendidikan dengan tujuan menanamkan keimanan dan ketakwaan kepada Allah S.W.T., akhlak mulia, serta tradisi pesantren untuk mengembangkan kemampuan, pengetahuan, dan keterampilan peserta didik untuk menjadi ahli ilmu agama Islam (mutafaqqih fiddin) dan / atau menjadi muslim yang memiliki keterampilan / keahlian untuk membangun kehidupan yang islami di masyarakat (H. A. Rahmat Rosyadi, 2014: 6-7).

Dasar yuridis digunakan sebagai dasar pengakuan atas metode membaca Al-Qur'an Yanbu'a yang digunakan di pondok pesantren sebagai lembaga keagamaan yang mengembangkan kemampuan, potensi, pengetahuan dan keterampilan individu untuk menghayati dan atau menjadi ahli ilmu agama Islam khususnya mempelajari Al-Qur'an sebagai sumber utama ajaran agama Islam.

3) Dasar Psikologis

Membaca Al-Qur'an selain bernilai ibadah dapat memberikan ketenangan jiwa bagi yang membacanya karena di dalamnya 
terdapat syifaa (obat) yang dapat menentramkan jiwanya. Sesuai dengan firman Allah S.W.T. dalam Al-Qur'an Surat Yunus: 57
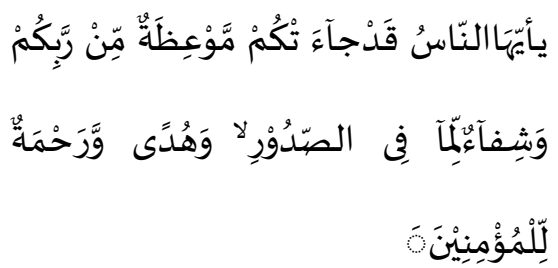

"Hai manusia, sesungguhnya telah datang kepadamu pelajaran dari Tuhanmu dan penyembuh bagi penyakit-penyakit (yang berada) dalam dada dan petunjuk serta rahmat bagi orang-orang yang beriman." (QS. Yunus: 57).

Ayat tersebut menerangkan secara ijmal, bagaimana Al-Qur'an memperbaiki jiwa manusia, dalam empat perkara, yakni:

1) Nasehat yang baik,

2) Obat bagi segala penyakit hati,

3) Petunjuk kepada jalan kebenaran dan keyakinan, dan

4) Rahmat bagi orang-orang yang beriman (Ahmad Mustafa AlMaraghi, 1993: 235-236).

\section{c. Metode Yanbu'a}

1) Metode Baca Al-Qur'an Yanbu'a Metode Yanbu'a merupakan panduan baca tulis dan menghafal Al-Qur'an ciptaan Tim Penyusun yang dipimpin oleh KH. M. Ulil Albab Arwani, beliau adalah putera kyai kharismatik dari Kudus yang dikenal sebagai ahli ilmu Al-Qur'an yaitu KH. Muhammad Arwani.

Dalam Buku Yanbu'a Sambutan Sesepuh, kata Yanbu'a yaitu sumber, nama ini diambil dari nama pondok Tahfidh Al-Qur'an yang sangat terkenal di Kudus yaitu Yanbu'ul Qur'an berarti sumber Al-Qur'an. Nama yang sangat digemari dan disenangi oleh sang guru besar AlQur'an dari Kudus yaitu simbah KH. M. Arwani Amin yang silsilah keturunannya sampai pada Pangeran Diponegoro.

Kata Yanbu'a diambil dari ayat AlQur'an tentang arti kata Yanbu'a dalam firman Allah S.W.T.

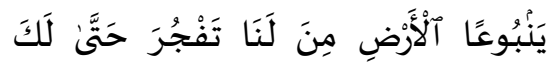

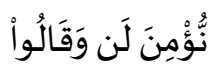

"Dan mereka berkata, "kami tidak akan percaya kepadamu (Muhammad) sebelum engkau memancarkan mata air dari bumi untuk kami.” (Q.S. AlIsra: 90)

Munculnya metode Yanbu'a merupakan usulan dari alumni Pondok tahfidh Yanbu'ul Qur'an, masyarakat 
Kudus serta Lembaga Pendidikan Ma'arif dan Muslimat terutama dari cabang Kudus dan Jepara. Dari pihak pondok menganggap sudah cukup metode pembelajaran yang ada, tetapi karena desakan yang terus menerus dan memang dipandang perlu, terutama untuk menjalin keakraban antara alumni dengan pondok serta untuk menjaga dan memelihara keseragaman bacaan AlQur'an Seperti dikutip oleh Fitri Rahmawati dalam dalam buku karya KH. M. UlinNuha dkk, 2004: 13).

Penulisan bacaan dalam buku Yanbu'a menggunakan Al-Qur'an dengan rasm Utsmani, yaitu mushaf yang ditulis pada zaman Khalifah Utsman Bin Affan (M. Ulinnuha Arwani, 2010: 5). Bacaan AlQur'an dalam metode Yanbu'a mengikuti riwayat salah satu Imam yaitu Imam Hafs. Beliau adalah ulama ahli qira 'at Al-Qur'an dari kota Kuffah yang merupakan perawi dari Imam 'Ashim (M. Sya'roni Ahmadi, 1997: 20). Riwayat Imam Hafs dari Imam 'Asim dari Abdullah Al-Salam dari sahabat 'Utsman bin 'Affan dari Rasulullah S.A.W.

Penyampaian materi pembelajaran dengan metode Yanbu'a dilakukan dengan berbagai macam metode, antara lain:

a) Musyafachah, yaitu guru membaca terlebih dahulu kemudian murid menirukan. Dengan cara ini guru dapat menerapkan membaca huruf dengan benar melalui lidahnya. Sedangkan siswa akan dapat melihat dan menyaksikan langsung praktek keluarnya huruf dan lidah guru untuk ditirukannya.

b) 'Ardul Qiro'ah, yaitu murid membaca di depan guru sedangkan guru menyimaknya. Sering juga cara ini sebut dengan sorogan.

c) Pengulangan yaitu mengulangulang bacaan, sedangkan murid menirukannya kata per kata atau kalimat per kalimat, juga secara berulang-ulang hingga terampil dan benar (Arwani, 2004: 2).

Arwani juga mengungkapkan, bahwa adapun tujuan Metode Yanbu'a secara khusus antara lain:

a) Dapat membaca Al-Qur'an dengan tartil, meliputi:

1. Makhraj sebaik mungkin.

2. Mampu membaca Al-Qur'an dengan bacaan yang bertajwid.

3. Mengenal bacaan gharib dan bacaan yang musykilat.

4. Hafal (paham) ilmu tajwid secara praktis.

b) Mampu menulis Arab dengan baik dan benar.

Metode Yanbu'a isinya disusun guna mengembangkan potensi anak usia dini (pra sekolah) 
dengan disesuaikan berdasarkan umur dan tingkatan kemampuannya dimulai dari jilid I, II, III, IV, V, VI sampai jilid VII. Namun dalam prakteknya metode ini dapat digunakan oleh semua kalangan yang ingin belajar memperbaiki bacaan Al-Qur'an baik tingkat formal maupun non formal.

2) Kelebihan Metode Yanbu'a

Di antara kelebihan Yanbu'a adalah:

a) Tulisan disesuaikan dengan Rosm Utsmaniy

b) Tanda-tanda baca dan waqof diarahkan kepada tanda-tanda yang sekarang digunakan di dalam Al-Qur'an yang diterbitkan di negara-negara Islam dan Timur Tengah yaitu tanda-tanda yang dirumuskan oleh ulama' salaf.

c) Ada tambahan tanda baca yang memudahkan untuk mempelajari teknik membaca.

3) Kurikulum Metode Yanbu'a

Kurikulum dalam dunia pendidikan mengandung pengertian sebagai rencana dan pengaturan tentang sejumlah mata pelajaran yang harus dipelajari peserta didik dalam menempuh pendidikan di lembaga pendidikan (Ma'as Shobirin, 2016: 14).

Heni Kurniawati mengugkapkan, bahwa Karakteristik kurikulum Yanbu'a:

1. Menekankan pada ketercapaian kompetensi siswa baik secara individual maupun klasikal, hal ini berdasarkan pemikiran Nurcholis Majid, seperti dikutip oleh Zamaksyari Dhofier 1997.

2. Menggunakan pendekatan dan metode yang bervariasi dalam proses pembelajaran

3. Menekankan pada proses dan hasil belajar dalam upaya penguasaan pencapaian kompetensi (membaca, menulis dan menghafal)

4) Cara Mengajar Metode Yanbu'a

1. Guru menyampaikan salam sebelum kalam dan jangan salam sebelum murid tenang.

2. Guru membacakan hadlroh (hal. 46 Juz 1) kemudian murid membaca Fatichah dan do'a pembuka.

3. Guru berusaha supaya anak aktiv serta mandiri / CBSA (Cara Bela 
4. Guru jangan menuntun bacaan murid tetapi membimbing dengan cara:

a. Menerangkan pokok pelajaran (yang bergaris bawah).

b. Memberi contoh yang benar.

c. Menyimak bacaan murid dengan sabar, teliti dan tegas.

d. Menegur bacaan yang salah dengan isyarat, ketukan atau selain dari itu dan jika sudah tidak bisa baru ditunjukkan yang benar.

e. Bila anak sudah lancar dan benar guru menaikkan halaman I sampai dengan beberapa halaman menurut kemampuan murid.

f. Bila anak belum lancar dan benar atau masih banyak kesalahan jangan dinaikkan dan harus mengulang.

g. Waktu belajar 60 - 75 menit dan dibagi menjadi tiga bagian:

- 15-20 menit untuk membaca do'a, absensi, menerangkan pokok pelajaran atau membaca secara klasikal.
- 30-40 menit untuk mengajar secara individu / menyimak anak satu persatu dan bagi yang tidak / belum maju agar belajar menulis sesuai dengan kotak yang ada pada setiap juz.

- 10-15 menit memberi pelajaran tambahan (seperti fasholatan, Do'a, dan lain sebagainya) nasihat dan do'a penutup.

Setiap halaman umumnya terdiri dari empat kotak:

1. Kotak I: Materi pelajaran utama, keterangannya diawali dengan tanda titik.

2. Kotak II: Materi pelajaran tambahan, keterangannya diawali dengan tanda segitiga.

3. Kotak III: Materi pelajaran menulis, keterangannya diawali dengan tanda segi empat.

4. Kotak IV: Tempat keterangan

- Kotak II ikut dibaca oleh murid, bila perlu diterangkan.

- Kotak III untuk belajar menulis, bila perlu diterangkan (tidak ikut dibaca). 
5) Evaluasi Pembelajaran Metode Yanbu'a

Rangkaian akhir dari suatu proses pendidikan Islam yakni melaksanakan evaluasi pendidikan sebagai bentuk pertanggung jawaban penyelenggaraan pendidikan guna menentukan proses, kemajuan dan perbaikan hasil belajar peserta didik secara

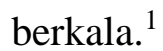

\section{Penyajian Data dan Analisis Data}

\section{Pengujian Hipotesis}

\section{a. Uji Koefisien Korelasi}

Uji korelasi dilakukan untuk mengukur seberapa besar pengaruh antara variabel $\mathrm{X}$ terhadap variabel Y.

Untuk memudahkan penulis dalam mengolah dan menganalisis data, serta untuk mengurangi peluang kesalahan dalam perhitungan masing-masing nilai setiap variabel berikut penulis paparkan dalam tabel pengaruh penggunaan metode Yanbu'a terhadap kemampuan membaca Al-Qur'an sebagai berikut:

1 Undang-undang Nomor 20 Tahun 2003 tentang Sistem Pendidikan Nasional, Pasal 1, Angka 21, Pasal 58 ayat 1. Dalam H. A. Rahmat Rosyadi.
Tabel 4.7

Hasil Penjumlahan Variabel X dan Y

\begin{tabular}{|c|c|c|c|c|c|}
\hline $\begin{array}{c}\text { NO } \\
\text { RESPO } \\
\text { NDEN }\end{array}$ & $\mathbf{X}$ & $\mathbf{Y}$ & XY & $X^{2}$ & $\mathbf{Y}^{2}$ \\
\hline 1 & 93 & 94 & $\begin{array}{c}874 \\
2\end{array}$ & $\begin{array}{c}864 \\
9\end{array}$ & $\begin{array}{c}883 \\
6\end{array}$ \\
\hline 2 & 57 & 57 & $\begin{array}{c}324 \\
9\end{array}$ & $\begin{array}{c}324 \\
9\end{array}$ & $\begin{array}{c}324 \\
9\end{array}$ \\
\hline 3 & 94 & 94 & $\begin{array}{c}883 \\
6\end{array}$ & $\begin{array}{c}883 \\
6\end{array}$ & $\begin{array}{c}883 \\
6\end{array}$ \\
\hline 4 & 52 & 66 & $\begin{array}{c}343 \\
2\end{array}$ & $\begin{array}{c}270 \\
4\end{array}$ & $\begin{array}{c}435 \\
6\end{array}$ \\
\hline 5 & 56 & 60 & $\begin{array}{c}336 \\
0\end{array}$ & $\begin{array}{c}313 \\
6\end{array}$ & $\begin{array}{c}360 \\
0\end{array}$ \\
\hline 6 & 94 & 97 & $\begin{array}{c}911 \\
8\end{array}$ & $\begin{array}{c}883 \\
6\end{array}$ & $\begin{array}{c}940 \\
9\end{array}$ \\
\hline 7 & 95 & 95 & $\begin{array}{c}902 \\
5\end{array}$ & $\begin{array}{c}902 \\
5\end{array}$ & $\begin{array}{c}902 \\
5\end{array}$ \\
\hline 8 & 93 & 94 & $\begin{array}{c}874 \\
2\end{array}$ & $\begin{array}{c}864 \\
9\end{array}$ & $\begin{array}{c}883 \\
6\end{array}$ \\
\hline 9 & 59 & 56 & $\begin{array}{c}330 \\
4\end{array}$ & $\begin{array}{c}348 \\
1\end{array}$ & $\begin{array}{c}313 \\
6\end{array}$ \\
\hline 10 & 95 & 93 & $\begin{array}{c}883 \\
5\end{array}$ & $\begin{array}{c}902 \\
5\end{array}$ & $\begin{array}{c}864 \\
9\end{array}$ \\
\hline 11 & 63 & 56 & $\begin{array}{c}352 \\
8\end{array}$ & $\begin{array}{c}396 \\
9\end{array}$ & $\begin{array}{c}313 \\
6\end{array}$ \\
\hline 12 & 64 & 88 & $\begin{array}{c}563 \\
2\end{array}$ & $\begin{array}{c}409 \\
6\end{array}$ & $\begin{array}{c}774 \\
4\end{array}$ \\
\hline
\end{tabular}

(2014). Pendidikan Islam dalam Perspektif Pendidikan Nasional. Bogor: IPB Press. hlm. 147. 


\begin{tabular}{|c|c|c|c|c|c|}
\hline 13 & 61 & 61 & $\begin{array}{c}372 \\
1\end{array}$ & $\begin{array}{c}372 \\
1\end{array}$ & $\begin{array}{c}372 \\
1\end{array}$ \\
\hline 14 & 64 & 65 & $\begin{array}{c}416 \\
0\end{array}$ & $\begin{array}{c}409 \\
6\end{array}$ & $\begin{array}{c}422 \\
5\end{array}$ \\
\hline 15 & 68 & 75 & $\begin{array}{c}510 \\
0\end{array}$ & $\begin{array}{c}462 \\
4\end{array}$ & $\begin{array}{c}562 \\
5\end{array}$ \\
\hline 16 & 55 & 63 & $\begin{array}{c}346 \\
5\end{array}$ & $\begin{array}{c}302 \\
5\end{array}$ & $\begin{array}{c}396 \\
9\end{array}$ \\
\hline 17 & 95 & 96 & $\begin{array}{c}912 \\
0\end{array}$ & $\begin{array}{c}902 \\
5\end{array}$ & $\begin{array}{c}921 \\
6\end{array}$ \\
\hline 18 & 92 & 94 & $\begin{array}{c}864 \\
8\end{array}$ & $\begin{array}{c}846 \\
4\end{array}$ & $\begin{array}{c}883 \\
6\end{array}$ \\
\hline 19 & 93 & 96 & $\begin{array}{c}892 \\
8\end{array}$ & $\begin{array}{c}864 \\
9\end{array}$ & $\begin{array}{c}921 \\
6\end{array}$ \\
\hline 20 & 95 & 88 & $\begin{array}{c}836 \\
0\end{array}$ & $\begin{array}{c}902 \\
5\end{array}$ & $\begin{array}{c}774 \\
4\end{array}$ \\
\hline 21 & 96 & 97 & $\begin{array}{c}931 \\
2\end{array}$ & $\begin{array}{c}921 \\
6\end{array}$ & $\begin{array}{c}940 \\
9\end{array}$ \\
\hline 22 & 59 & 65 & $\begin{array}{c}383 \\
5\end{array}$ & $\begin{array}{c}348 \\
1\end{array}$ & $\begin{array}{c}422 \\
5\end{array}$ \\
\hline 23 & 61 & 63 & $\begin{array}{c}384 \\
3\end{array}$ & $\begin{array}{c}372 \\
1\end{array}$ & $\begin{array}{c}396 \\
9\end{array}$ \\
\hline 24 & 54 & 58 & $\begin{array}{c}313 \\
2\end{array}$ & $\begin{array}{c}291 \\
6\end{array}$ & $\begin{array}{c}336 \\
4\end{array}$ \\
\hline 25 & 56 & 66 & $\begin{array}{c}369 \\
6\end{array}$ & $\begin{array}{c}313 \\
6\end{array}$ & $\begin{array}{c}435 \\
6\end{array}$ \\
\hline 26 & 67 & 95 & $\begin{array}{c}636 \\
5\end{array}$ & $\begin{array}{c}448 \\
9\end{array}$ & $\begin{array}{c}902 \\
5\end{array}$ \\
\hline 27 & 79 & 75 & $\begin{array}{c}592 \\
5\end{array}$ & $\begin{array}{c}624 \\
1\end{array}$ & $\begin{array}{c}562 \\
5\end{array}$ \\
\hline
\end{tabular}

\begin{tabular}{|c|c|c|c|c|c|}
\hline 28 & 62 & 56 & $\begin{array}{c}347 \\
2\end{array}$ & $\begin{array}{c}384 \\
4\end{array}$ & $\begin{array}{c}313 \\
6\end{array}$ \\
\hline 29 & 64 & 64 & $\begin{array}{c}409 \\
6\end{array}$ & $\begin{array}{c}409 \\
6\end{array}$ & $\begin{array}{c}409 \\
6\end{array}$ \\
\hline 30 & 93 & 94 & $\begin{array}{c}874 \\
2\end{array}$ & $\begin{array}{c}864 \\
9\end{array}$ & $\begin{array}{c}883 \\
6\end{array}$ \\
\hline$\Sigma$ & $\mathbf{2 2}$ & $\mathbf{2 3}$ & $\mathbf{1 7 9}$ & $\mathbf{1 7 4}$ & $\mathbf{1 8 7}$ \\
& $\mathbf{2 9}$ & $\mathbf{2 1}$ & $\mathbf{7 2 3}$ & $\mathbf{0 7 3}$ & $\mathbf{4 0 5}$ \\
\hline
\end{tabular}

Dari hasil data di atas maka dapat diketahui:

\begin{tabular}{|c|c|c|c|c|c|}
\hline $\mathbf{N}$ & $\sum$ & $\sum$ & $\sum \mathbf{X}$ & $\sum \mathbf{X}^{\mathbf{2}}$ & $\sum \mathbf{Y}^{\mathbf{2}}$ \\
\hline 3 & $\mathbf{X}$ & $\mathbf{Y}$ & $\mathbf{Y}$ & & \\
\hline 0 & 29 & 23 & 179 & 174 & 187 \\
21 & 723 & 073 & 405 \\
\hline
\end{tabular}

Setelah diketahui hasil data dari kedua variabel, maka selanjutnya peneliti mencari nilai koefisien korelasi yang dapat mengetahui seberapa besar pengaruh penggunaan penggunaan metode Yanbu'a terhadap kemampuan membaca Al-Qur'an santri di Pondok Pesantren Al-Badar Pamijahan Bogor. Maka dapat digunakan rumus korelasi Pearson Product Moment dengan mendasarkan diri pada skor sebagai berikut: 


$$
\begin{aligned}
\mathrm{r}_{\mathrm{xy}} & =\frac{N \sum X Y-\left(\sum X\right)\left(\sum Y\right)}{\sqrt{\left[N \sum X^{2}-\left(\sum X\right)^{2}\right]\left[N \sum^{2}-\left(\sum Y\right)^{2}\right.}} \\
& =
\end{aligned}
$$

$\frac{30(179723)-(2229)(2321)}{\sqrt{\left[30(174073)-(2229)^{2}\right]\left[30(187405)-(2321)^{2}\right.}}$

$=$

$$
\begin{aligned}
& \frac{5391690-5173509}{\sqrt{[(5222190-4968441)][(5622150-5387041)]}} \\
& =\frac{218181}{\sqrt{[253749][235109]}} \\
& =\frac{218181}{\sqrt{59658673641}} \\
& =\frac{218181}{244251,2510}=0,893 \\
& =0,893
\end{aligned}
$$

Dari perhitungan $r_{x y}$ sebesar 0,893 angka indeks korelasi yang diperoleh tidak bertanda negatif. Hal ini berarti bahwa korelasi antara variabel $\mathrm{X}$ (Penggunaan Metode Yanbu'a) dan variabel Y (Kemampuan Membaca Al-Qur'an santri) terdapat hubungan yang searah, dengan istilah lain: terdapat korelasi positif di antara kedua variabel tersebut. Artinya, penggunaan metode Yanbu'a di pondok pesantren Al-Badar yang baik, maka kemampuan membaca Al-Qur'an santri pun akan baik, demikian juga sebaliknya.

Apabila kita melihat besarnya nilai $r_{x y}$ $=0,893$ terdapat pada kisaran antara 0,700,89 yang artinya korelasi antara variabel antara variabel $\mathrm{X}$ (penggunaan metode
Yanbu'a) terhadap variabel Y (kemampuan membaca Al-Qur'an), termasuk ke dalam kategori yang kuat/tinggi.

$\mathrm{r}_{\mathrm{xy}}$ tabel pada taraf signifikan $5 \%$ dan derajat kebebasan (dk) 28 diperoleh sebesar 0,374 . Dengan demikian $r_{x y}$ hitung lebih besar dibandingakan dengan $r_{x y}$ tabel $(0,893$ $>0,374)$.

\section{b. Uji Signifikansi}

Untuk menguji signifikansi digunakan rumus sebagai berikut:

$$
\begin{aligned}
T_{\text {hitung }} & =\frac{r x y \sqrt{n-2}}{\sqrt{1-r^{2}}} \\
& =\frac{0,893 \sqrt{30-2}}{\sqrt{1-(0,893)^{2}}} \\
& =\frac{0,893 \sqrt{28}}{\sqrt{1-(0,893)^{2}}} \\
& =\frac{(0,893)(5,30)}{\sqrt{1-0,780}} \\
& =\frac{4,73}{\sqrt{0,22}} \\
& =\frac{4,73}{0,470} \\
& =10,06
\end{aligned}
$$

Sebelum membandingkan thitung dengan $t_{\text {tabel }}$ terlebih dahulu mengetahui besarnya

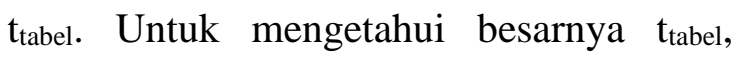
maka terlebih dahulu diketahui besarnya $\mathrm{dk}$ (derajat kebebasan) dengan rumus sebagai berikut:

$\begin{array}{ll}\mathrm{dk} & =\mathrm{N}-2 \\ \mathrm{dk} & =30-2 \\ \mathrm{dk} & =28\end{array}$


Dengan diperolehnya $\mathrm{dk}$ (derajat kebebasan), maka didapat $\mathrm{t}_{\text {tabel }}=2,048$ untuk taraf signifikansi $0,05 \%$. Dari hasil perhitungan ternyata $t_{\text {hitung }}>t_{\text {tabel }}(10,06>2$, 048). Maka kesimpulannya terdapat korelasi yang signifikan antara variabel $\mathrm{X}$ (penggunaan metode Yanbu'a) terhadap variabel Y (kemampuan membaca AlQur'an).

Berdasarkan hasil uji korelasi dan uji signifikansi di atas, telah terbukti bahwa $t_{\text {hitung }}$ lebih besar dari $t_{\text {tabel}}$. Maka hipotesis alternatif $\left(\mathrm{H}_{\mathrm{a}}\right)$ diterima dan hipotesis nihil $\left(\mathrm{H}_{0}\right)$ ditolak. Sehingga dapat disimpulkan bahwa terdapat pengaruh yang tinggi antara penggunaan metode Yanbu'a terhadap kemampuan membaca Al-Qur'an santri di Pondok Pesantren Al-Badar.

\section{c. Uji Koefisien Determinan}

Setelah dilakukan uji korelasi dan uji signifikan, maka didapat hasil bahwa terdapat pengaruh yang kuat/tinggi antara variabel $\mathrm{X}$ dan $\mathrm{Y}$. Kemudian untuk mengetahui seberapa besar kontribusi (sumbangan) variabel $\mathrm{X}$ dalam menunjang variabel $\mathrm{Y}$, maka harus dihitung terlebih dahulu koefisien determinan atau yang disebut dengan coefisien of determination (koefisien penentu) dengan rumus sebagai berikut:

$$
\begin{aligned}
\mathrm{KD} & =r^{2} \times 100 \% \\
& =(0,893)^{2} \times 100 \% \\
& =0,80 \times 100 \% \\
& =80 \%
\end{aligned}
$$

Berdasarkan pengujian di atas menunjukkan bahwa kontribusi pengaruh penggunaan metode Yanbu'a terhadap kemampuan membaca AlQur'an adalah $80 \%$ artinya $20 \%$ lainnya dipengaruhi oleh faktor lain yang tidak diteliti dalam penelitian ini.

\section{Interpretasi Data}

Interpretasi data yang disajikan berikut ini mengacu pada permasalahan penelitian yang telah di rumuskan. Dari hasil analisis penelitian membuktikan bahwa penggunaan metode Yanbu'a di pondok pesantren Al-Badar termasuk dalam kategori cukup. Hal ini dapat dilihat dari hasil pencapaian skor rata-rata angket penggunaan metode Yanbu'a yang disebarkan kepada 30 santri dengan nilai 74,3 pencapaian nilai terendah 52 dan nilai tertinggi 96. Sedangkan kemampuan membaca Al-Qur'an santri di pondok pesantren Al-Badar juga termasuk dalam kategori cukup. Hal ini dapat dilihat dari hasil pencapaian skor angket yang diperoleh dengan nilai rata-rata 77,3 dengan nilai terendah 56 dan nilai tertinggi 97.

Dari perhitungan $r_{x y}$ sebesar 0,893 angka indeks korelasi yang diperoleh tidak 
bertanda negatif. Hal ini menunjukkan bahwa korelasi antara variabel $\mathrm{X}$ (Penggunaan Metode Yanbu'a) dan variabel Y (Kemampuan Membaca AlQur'an) terdapat hubungan yang searah, dengan istilah lain: terdapat korelasi positif di antara kedua variabel tersebut. Berdasarkan hasil perhitungan $\mathrm{r}_{\mathrm{xy}}$ yang diperoleh sebesar 0,893 , terletak antara 0,70 - 0,90 dalam tabel korelasi product moment yang dikemukakan dapat dinyatakan bahwa antara variabel $\mathrm{X}$ dan variabel $\mathrm{Y}$ memiliki pengaruh yang kuat atau tinggi. Dari nilai $\mathrm{dk}=28$ dengan taraf kepercayaan (signifikansi) $95 \%$ diperoleh nilai $\mathrm{r}_{\text {tabel }}$ 0,374. Hasil dari pencarian $r_{\text {tabel }}$ tersebut dikonsultasikan dengan rumus hipotesis didapat $0,893>0,374$ atau $r_{h i t}>r_{\text {tabel, }}$ hal ini mengandung pengertian bahwa terdapat pengaruh antara penggunaan metode Yanbu'a terhadap kemampuan membaca Al-Qur'an.

Dengan diperolehnya $\mathrm{dk}$ (derajat kebebasan $)=28$ dengan thitung 10,06 untuk taraf signifikansi $0,05 \%$ diperoleh 2,048. Hal ini berarti bahwa thitung lebih besar dari $t_{\text {tabel }}(10,06>2,048)$. Hasil pengujian terhadap koefisien korelasi yang diperoleh dapat disimpulkan bahwa $r_{x y}=0,893$ terdapat korelasi positif signifikan dalam taraf yang tinggi. Dengan demikian hipotesa alternatif $\left(\mathrm{H}_{\mathrm{a}}\right)$ diterima dan hipotesa nihil $\left(\mathrm{H}_{0}\right)$ ditolak.

Untuk menyatakan besar kecilnya sumbangan variabel $\mathrm{X}$ terhadap variabel $\mathrm{Y}$ dinyatakan dalam koefisien determinan. Variabel yang mempengaruhi secara signifikan terhadap tinggi rendahnya kemampuan membaca Al-Qur'an santri secara nyata dipengaruhi oleh penggunaan metode Yanbu'a sebesar $80 \%$ yang artinya $20 \%$ lainnya dipengaruhi oleh faktor lain yang tidak diteliti dalam penelitian ini.

\section{E. KESIMPULAN}

Setelah peneliti melaksanakan penelitian dengan data-data yang telah dihimpun dan dianalisis, maka kesimpulan penelitian yang dapat diambil ialah sebagai berikut:

1. Penggunaan metode Yanbu'a di Pondok Pesantren Al-Badar Desa Pamijahan Kecamatan Pamijahan Kabupaten Bogor termasuk dalam kategori cukup. Hal ini dibuktikan dari pencapaian nilai rata-rata skor angket (Penggunaan Metode Yanbu'a) menunjukkan nilai 74,3 dengan nilai tertinggi 96 dan nilai terendah 52 .

2. Kemampuan membaca Al-Qur'an santri di Pondok Pesantren Al-Badar termasuk dalam kateegori baik. Hal ini dibuktikan dari pencapaian nilai skor 
angket (Kemampuan Membaca AlQur'an) yang menunjukkan nilai 77,3 dengan nilai tertinggi 97 dan nilai terendah 56.

3. Dari perhitungan $r_{x y}$ sebesar 0,893 angka indeks korelasi yang diperoleh tidak bertanda negatif. Hal ini berarti bahwa korelasi antara variabel $\mathrm{X}$ (Penggunaan Metode Yanbu'a) dan variabel Y (Kemampuan Membaca AlQur'an santri) terdapat hubungan yang searah, dengan istilah lain: terdapat korelasi positif di antara kedua variabel tersebut. Berdasarkan hasil perhitungan $r_{x y}$ yang diperoleh sebesar 0,893 , terletak antara $0,70-0,90$ dalam tabel korelasi product moment yang dikemukakan dapat dinyatakan bahwa antara variabel $\mathrm{X}$ dan variabel $\mathrm{Y}$ memiliki pengaruh yang kuat atau tinggi. Untuk menyatakan besar kecilnya sumbangan variabel $\mathrm{X}$ terhadap variabel Y dinyatakan dalam koefisien determinan. Variabel yang mempengaruhi secara signifikan terhadap tinggi rendahnya kemampuan membaca Al-Qur'an santri secara nyata dipengaruhi oleh penggunaan metode Yanbu'a sebesar $80 \%$ yang artinya 20\% lainnya dipengaruhi oleh faktor lain yang tidak diteliti dalam penelitian ini. Dari nilai $\mathrm{df}=28$ dengan taraf kepercayaan (signifikansi) 95\% diperoleh nilai $r_{\text {tabel }} 0,374$. Hasil dari pencarian $r_{\text {tabel }}$ tersebut dikonsultasikan dengan rumus hipotesis didapat 0,893 $(0,893>0,374)$ atau $r_{\text {hit }}>r_{\text {tabel, }}$ hal ini mengandung pengertian bahwa terdapat pengaruh yang kuat antara penggunaan metode Yanbu'a dengan kemampuan membaca Al-Qur'an di pondok pesantren Al-Badar Desa Pamijahan Kecamatan Pamijahan Kabupaten Bogor. Dengan demikian hipotesis alternatif $\left(\mathrm{H}_{\mathrm{a}}\right)$ yang menyatakan bahwa penggunaan metode Yanbu'a berpengaruh terhadap kemampuan membaca Al-Qur'an santri pondok pesantren Al-Badar diterima, sedangkan hipotesis nihil $\left(\mathrm{H}_{0}\right)$ yang menyatakan bahwa penggunaan metode Ymanbu'a tidak berpengaruh terhadap kemampuan membaca Al-Qur'an santri pondok pesantren Al-Badar di tolak.

\section{DAFTAR PUSTAKA}

Abady, M. Yusrie. (2012). Pedoman Penulisan Karya Ilmiah. Jakarta: Rabbani Press.

Ahmadi, M. Sya'roni. (1997). Faidl alAsaniy 'ala Al-Hirz Al-Amaniy wa 
Wajh Al-Tahaniy. Kudus: Mubarakatan Thayyibah.

Arikunto, Suharsimi. (2005). Manajemen

Pendidikan. Jakarta: Rineka Cipta.

Al-Mahmud, Syaikh Muhammad. Matan

Hidayatul Mustafid Fiy Ahkami At-

Tajwid.

Al-Jamzuri, Syaikh Sulaiman. (1089 H.),

Matan Fathul Athfal. Madinah:

Maktabah Al-Madiinah.

Al-Qudsi, Libni Muhammad Arwani Amin.

(1997). Kholashoh I'aanatul

Musyafihin. Kudus: Yayasan

Arwaniyyah.

Arnold Ngglili, Ricky. (2016). Belajar Any

Where Learning to Know, Learning to do, Learning to Live Together and Learning to be. Jakarta: Guepedia.

Arwani, M. Ulinnuha. Dkk. (2004).

Bimbingan Cara Mengajar yanbu'a.

Kudus: Pondok Tahfidz Yanbu'ul

Qur'an.

Arwani, M. Ulinnuha. (2010). Thariqah

Baca Tulis dan Menghafal Al-Qur'an

Yanbu'a Jilid 6. Kudus: Yayasan Arwaniyyah Kudus (BAPENU Arwaniyyah).

Bambang Saiful Ma'arif. (2001). Teknik Menghafal Al-Qur'an. Bandung: Sinar Baru.
Departemen Agama RI. Al-Qur'an dan Terjemahnya. Semarang: Syaamil Qur'an.

Djamarah, Syaifullah Bahri. (2008). Rahasia Sukses Belajar. Jakaarta: Rineka Cipta.

Hamidy, Zainuddin. (2006). Terjemah Shahih Bukhari. Jakarta: Wijaya.

Hatta, Moh. Zaini dan Moh. Rais. (2003). Belajar Mudah membaca Al-Qur'an dan Tempat Keluarnya Huruf. Jakarta: Daarul Ulum Press.

Hidayat, Sedarmayanti dan Syarifudin. (2011). Metodologi Penelitian. Bandung: Bandar Maju.

Madjid, Nurcholis. (1997). Tradisi Pesantren: Pendidikan Alternatif Masa Depan. Jakarta: Gema Insani Press.

Munir, Sudarmono dan Ahmad. Ilmu Tajwid dan Seni Baca Al-Qur'an.

Mustafa Al-Maraghi, Ahmad. (1993). Tafsir Al-Maraghi Juz XI. Semarang: Toha Putra.

Nawawi, Abdul Mujib Isma'il dan Maria Ulfah. (1995). Pedoman Ilmu Tajwid. Surabaya: Karya Abdi Utama.

Poerwadarminta, W.J.S. (2011). Kamus Umum Bahasa Indonesia Edisi Ketiga. Jakarta: Balai Pustaka. 
Ramayulis. (2015). Dasar-dasar Kependidikan Suatu Pengantar Ilmu Pendidikan. Jakarta: Kalam Mulia.

Rosyadi, H.A. Rahmat. (2014). Pendidikan Islam dalam Perspektif Pendidikan Nasional. Bogor: IPB Press.

Sa'dulloh. (2008). 9 Cara Praktis Menghafal Al-Qur'an. Jakarta: Gema Insani.

Shobirin, Ma'as. (2016). Konsep dan Implementasi Kurikulum 2013 di Sekolah Dasar. Yogyakarta: Deepublish CV. Budi Utama.

Slameto. (2013). Belajar dan Faktor-faktor

Yang Mempengaruhinya. Jakarta: Rineka Cipta.

Sudijono, Anas. (2008). Pengantar Evaluasi Pendidikan. Jakarta: PT RajaGrafindo Persada.

Sugiono. (2010). Metode Penelitian Kuantitatif dan $R \& D$. Bandung: Alfabetha.

Syafi'i, A. Mas'ud. (2001). Pelajaran Tajwid. Bandung: Putra Jaya.

Syafruddin. (2003). Guru Profesional dan

Implementasi Kurikulum. Jakarta: Ciputat Press.

Syaodih, Nana. (2003). Perencanaan Pengajaran. Jakarta: Rineka Cipta.
Syarifuddin, Ahmad. (2008). Mendidik Anak Membaca, Menulis, dan Mencintai Al-Qur'an. Jakarta: Gema Insani Press.

Umaruddin, Muhammad. (2002). Buku Rangkuman Fiiy Ahkam At-Tajwiid. Bogor: Ma'had Siroojul Athfal.

Wahid, H. Ramli Abdul. (2002). Fadilah membaca Al-qur'an. Jakarta: PT RajaGrafindo Persada.

\section{Karya Ilmiah}

Rahmawati, Fitri. (2009). Skripsi Penerapan Metode Yanbu'a dalam Pembelajaran Baca Tulis Al-Qur'an di taman Pendidikan Al-Qur'an Husnut Tilawah Payaman Mejobo Kudus. Yogyakarta: UIN Sunan Kalijaga.

Kurniawati, Heni. (2008). Skripsi Efektivitas metode Yanbu'a dalam Pembelajaran Membaca Al-Qur'an di $T P Q$ Tamrinus Shibyan Karangrandu Pencangan Jepara. Semarang: Institut Agama Islam Negeri Walisongo.

\section{Peraturan Perundang-Undangan}

Undang-undang Nomor 20 Tahun 2003 tentang Sistem Pendidikan Nasional.

Peraturan Menteri Agama Republik Indonesia Nomor 13 Tahun 2014 Tentang Pendidikan Keagamaan Islam. 


\section{Sumber dari Internet}

http://www.upn.com/read/2013/07/07/1805

47/survey-11A=65-persen-muslim-

buta-Al-Qur'an Tanggal 29 Maret 2016.

http://www.republika.co.id/berita/dunia-

islam/islam-nusantara/14/11/12/news-

tingkat-buta-huruf-al-qur'an-masih-

tinggi-ini-komentar-kemenag, Tanggal

29 Mei 2016.

http://www.fai.umj.ac.id, Tanggal 09 April

2016.
Khaerul Yunus, Kesadaran Muslim

Perkotaan Makin Tinggi,

http://www.republika.co.id , Tanggal 10 April 2016.

http://www.Wallpapercartoonmuslimah.bl ogspot.com/2013/11/metode-

qiroati.html, Tanggal 10 April 2016.

http://www.republika.co.id/berita/duniaislam/islamnusantara/15/05/27/noywh 5-inilah-10-negara- dengan-populasimuslim-terbesar-di-dunia Tanggal 07 Januari 2017. 
